\title{
SIMULASI DAN ANALISIS JARINGAN METRO ETHERNET KOTA SURABAYA TAHUN 2028 DENGAN SIMULATOR RIVERBED MODELER ACADEMIC EDITION 17.5
}

\author{
Fitri Ananda*), Sukiswo dan Ajub Ajulian Zahra \\ Departemen Teknik Elektro, Universitas Diponegoro \\ Jl. Prof. Sudharto, SH, Kampus UNDIP Tembalang, Semarang 50275, Indonesia \\ ${ }^{*}$ E-mail: fiitriananda@gmail.com
}

\begin{abstract}
Abstrak
Kota Surabaya berdasarkan Kemkominfo merupakan salah satu kota dengan pengguna internet terbanyak di Indonesia yaitu 95 ribu pengguna. Metro Ethernet merupakan layanan komunikasi data untuk masyarakat wilayah perkotaan dengan bandwidth yang cukup besar. Oleh karena itu dibutuhkan suatu perencanaan jaringan untuk tahun-tahun mendatang sehingga memudahkan pengembangan jaringan demi terciptanya layanan metro ethernet Kota Surabaya yang handal dan memenuhi kebutuhan masyarakat secara optimal. Pada penelitian ini dilakukan simulasi perancangan jaringan metro ethernet Kota Surabaya tahun 2028 yang terdiri dari dua kondisi, yaitu jaringan kondisi flapping link dan kondisi normal. Jaringan kondisi flapping link digunakan untuk mengetahui kinerja dari dua routing protocol OSPF dan RIP. Hasil dari simulasi jaringan kondisi normal digunakan untuk menganalisis performansi masing-masing link Pada analisis flapping link, routing protocol OSPF menunjukkan kinerja lebih baik dibandingkan RIP, sehingga jaringan kondisi normal menggunakan routing protocol OSPF. Analisis performansi link dilakukan dengan mengukur parameter-parameter QoS berupa round trip delay (RTD), jitter dan packet loss. Hasil pengukuran menunjukkan bahwa RTD, jitter dan packet loss seluruh link masih dalam kondisi baik dengan nilai $<5 \mathrm{msec},<1 \mathrm{msec}$ dan $0.001 \%$.
\end{abstract}

Kata kunci: metro ethernet, flapping link, performansi link, routing protocol, round trip delay, jitter, packet loss.

\begin{abstract}
Surabaya City, based on the Ministry of Communication and Information, is one of the cities with the most internet users in Indonesia, which is 95 thousand users. Metro Ethernet is a data communication service for urban communities with considerable bandwidth. Therefore, a network planning is needed for the coming years so as to facilitate network development in order to create a reliable and optimal metro ethernet service in Surabaya. In this research, the simulation of the metro ethernet network design of Surabaya City in 2028 was carried out consisting of two conditions, the network flapping link conditions and normal conditions. The flapping link network is used to determine the performance of two OSPF and RIP routing protocols. The results of normal condition network simulation are used to analyze the performance of each link. In the flapping link analysis, OSPF routing protocol shows better performance than RIP, so that the normal network conditions use OSPF routing protocol. Link performance analysis is done by measuring QoS parameters in the form of round trip delay (RTD), jitter and packet loss. The measurement results show that the RTD, jitter and packet loss of all links are still in good condition with values $<5 \mathrm{msec},<1 \mathrm{msec}$ and $0.001 \%$.
\end{abstract}

Keywords: metro ethernet, flapping link, link performance, routing protocol, round trip delay, jitter, packet loss.

\section{Pendahuluan}

Perkembangan teknologi yang semakin pesat mengakibatkan masyarakat Indonesia tidak dapat melepaskan diri dari kegiatan komunikasi berbasis internet. Menurut data hasil survey Asosiasi Penyelenggara Jasa Internet Indonesia atau APJII tahun 2017, jumlah pengguna internet di Indonesia naik sekitar enam kali lipat dalam kurun waktu 10 tahun. Salah satu kota terbesar di pulau Jawa dengan pengguna internet terbanyak di Indonesia berdasarkan data Kementrian Komunikasi dan Informatika (Kemkominfo) adalah Kota Surabaya dengan 95 ribu pengguna internet. Oleh karena itu, dibutuhkan infrastruktur layanan telekomunikasi yang handal dan memadai untuk melayani permintaan masyarakat Kota Surabaya.

Metro Ethermet merupakan layanan komunikasi data dengan interface dan protocol ethernet yang bekerja pada layer OSI 1, 2 dan 3 dan menyediakan layanan 
telekomunikasi untuk masyarakat di wilayah perkotaan. Keunggulan metro ethernet yaitu mudah, sederhana dan dapat mengakomodasi layanan dengan bandwidth yang cukup besar. Dengan terus meningkatnya penggunaan dan permintaan masyarakat, beban trafik pada jaringan metro ethernet juga akan terus bertambah dan menyebabkan turunnya kinerja dari layanan metro ethernet. Oleh karena itu dibutuhkan suatu perencanaan jaringan untuk tahuntahun mendatang sehingga memudahkan dalam pengembangan jaringan demi terciptanya layanan metro ethernet yang handal dan dapat memenuhi kebutuhan pengguna secara optimal.

Pada penelitian ini akan dilakukan simulasi perancangan jaringan metro ethernet Kota Surabaya untuk kebutuhan tahun 2028 yang terdiri dari dua kondisi, yaitu jaringan metro etehrnet pada kondisi flapping link dan jaringan metro ethernet kondisi normal. Jaringan metro etehrnet dengan kondisi flapping link digunakan untuk mengetahui kinerja dari dua routing protocol OSPF dan RIP. Routing protocol dengan kinerja terbaik akan digunakan sebagai routing protocol pada jaringan kondisi normal. Hasil dari simulasi jaringan kondisi normal akan gunakan untuk menganalisis performansi link berdasarkan topologi jaringan dan peramalan trafik yang telah dilakukan[1]. Analisis performansi link ini akan menggunakan parameter round trip delay, jitter dan packet loss sebagai tolak ukur dalam menilai kinerja link apakah telah bekerja secara optimal dan sesuai dengan standarisasi yang telah ditetapkan oleh ITU-T sebagai standar internasional dibidang Telekomunikasi.

Dalam penelitian sebelumnya, Kristina R. Sitompul[2] melakukan analisis QoS pada jaringan metro ethernet dan kurang fokus mengenai peningkatan kapasitas link. Satya Yoga Pratama[3] melakukan peramalan trafik satu tahun kedepan jaringan metro ethernet dan analisis QoS dengan simulator OPNET 14.5.Ade Hurhayati dan kawankawan[4] membahas kinerja routing protocol OSPF pada salah satu ruas jaringan PT.Telekomunikasi Indonesa, berbeda dengan Arsalan Iqbal, dan kawan-kawan[5] yang melakukan analisis dan evaluasi kinerja dari tiga jenis roting protocols yaitu OSPF, RIP dan EIGRP dengan flapping links pada simulasi OPNET Modeler.

\section{Metode}

\subsection{Pemodelan Jaringan}

Perancangan simulasi jaringan metro ethernet pada penelitian ini akan dimodelkan dan disimulasikan dengan menggunakan perangkat lunak Riverbed Modeler versi 17.5 dimana jaringan yang disimulasikan merupakan hasil perencanaan jaringan metro ethernet setelah dilakukan dimensioning jaringan dan peramalan trafik untuk kebutuhan tahun 2028 serta hasil topologi jaringan ring baru berdasarkan penelitian sebelumnya. Hasil dari simulasi yang dilakukan digunakan untuk melakukan pengukuran performansi link menggunakan parameter- parameter meliputi round trip delay, jitter dan packet loss dengan mengacu pada standarisasi yang berlaku pada ITU$\mathrm{T}$.

Perancangan jaringan metro ethernet kota Surabaya dibuat berdasarkan diagram alir dan ditampilkan dalam bentuk tahapan-tahapan yang sistematis. Diagram alir perancangan dapat dilihat pada Gambar 1.

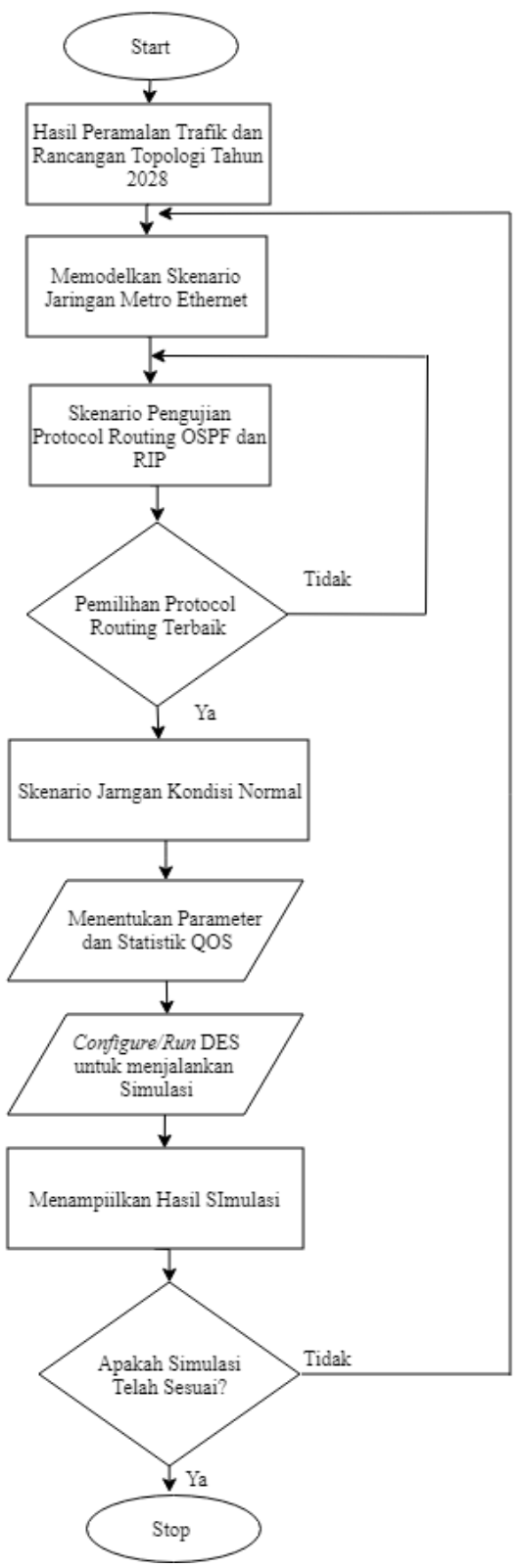

Gambar 1. Diagram Blok Sistem.

\subsubsection{Skenario Simulasi Jaringan untuk Evaluasi Kinerja Routing Protocol}

Protokol routing yang digunakan pada pengujian dalam simulasi adalah protocol routing OSPF (Open Shortest Path First) dan RIP (Routing Information Protocol). 
Pengujian dilakukan dengan metode flapping link yaitu metode dimana jaringan akan secara bergantian melewati rute pada setiap routing protocol sehingga menakibatkan up atau down secara bergantian pada jaringan[6]. Skenario pada simulasi jaringan untuk pengujian protocol routing memiliki 4 skenario dimana tiap protocol routing OSPF dan RIP memiliki 2 skenario simulasi. Pada scenario pertama akan dilakukan one link flapping dimana pada detik yang telah ditentukan link antara node ME-MNR dan ME-DMO dikonfigurasikan failure dan recovery. Sedangkan pada scenario kedua akan dilakukan konfigurasi two link flapping dimana pada konfigurasi failure dan recovery ditambahkan satu link tambahan yaitu diantara node router ME-KBL dan ME-MNR.

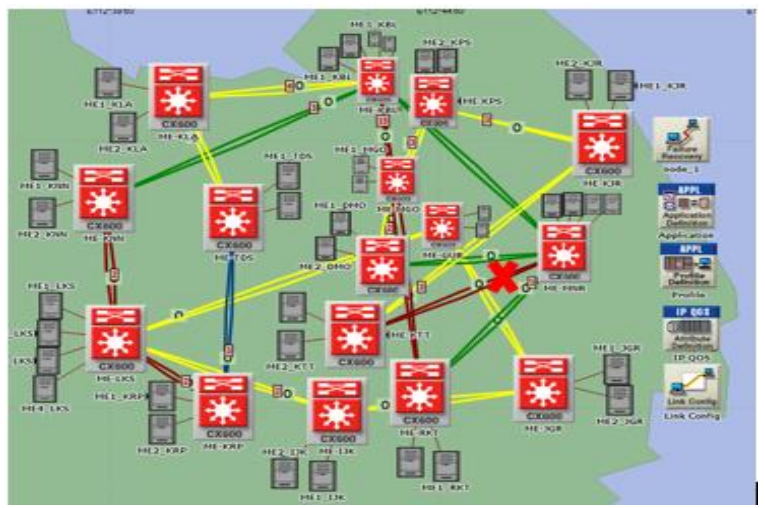

Gambar 2. One Link Flapping antara ME-MNR dan MEDMO.

Tabel 1. ME-MNR dan ME-DMO link failure dan recovery.

\begin{tabular}{cc}
\hline Waktu (s) & Status \\
\hline 240 & Failure \\
400 & Recovery \\
450 & Failure \\
510 & Recovery \\
620 & Failure \\
630 & Recovery \\
639 & Failure \\
800 & Recovery \\
850 & Failure \\
945 & Recovery \\
\hline
\end{tabular}

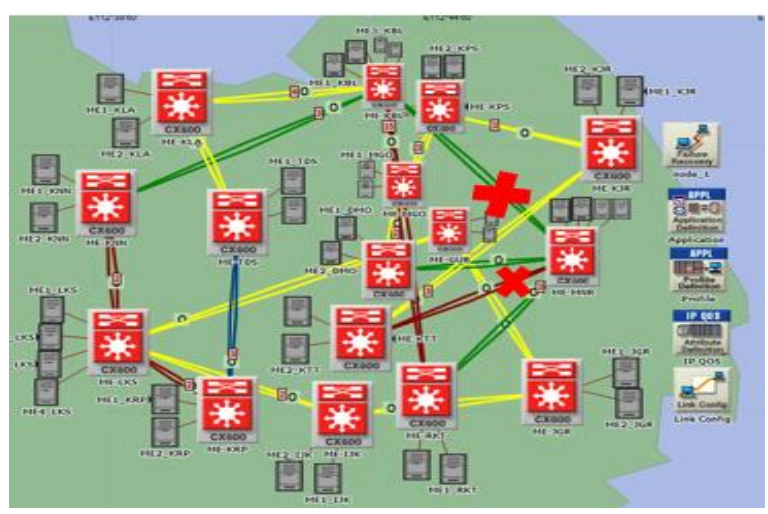

Gambar 3. Two Links Flapping antara ME-MNR dan MEDMO serta ME-KBL dan ME-MNR.
Tabel 2. ME-KBL dan ME-MNR link failure dan recovery.

\begin{tabular}{cc}
\hline Waktu (s) & Status \\
\hline 410 & Failure \\
450 & Recovery \\
490 & Failure \\
610 & Recovery \\
660 & Failure \\
697 & Recovery \\
820 & Failure \\
\hline
\end{tabular}

\subsubsection{Skenario Simulasi Jaringan Kondisi Normal}

Simulasi jaringan pada kondisi normal memiliki layout yang sama dengan simulasi jaringan untuk pengujian routing protocol, namun jaringan ini tidak menggunakan node link failure untuk melakukan flapping link. Skenario jaringan kondisi normal akan menggunakan routing protocol terbaik hasil dari analisis kinerja yang telah dilakukan. Skenario ini menyesuaikan topologi dan volume trafik hasil peramalan dari penelitian sebelumnya [1]. Gambar 4 menunjukkan tampilan scenario jaringan metro ethernet kondisi normal Kota Surabaya tahun 2028.

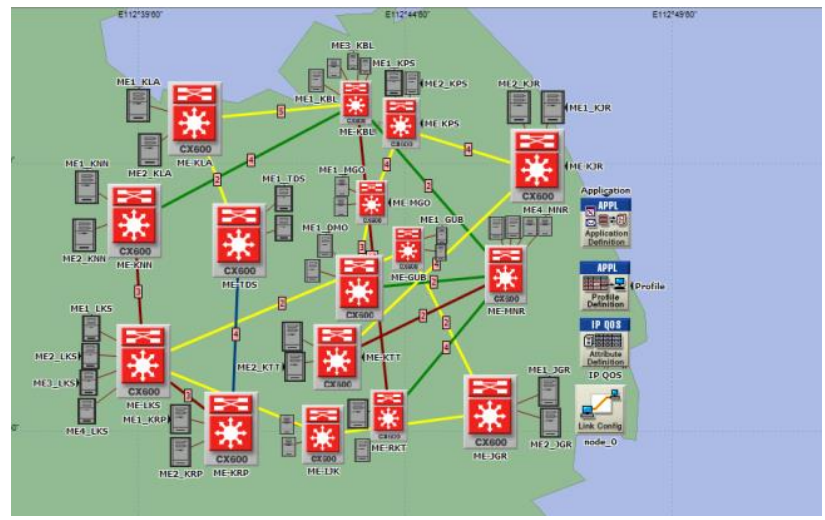

Gambar 4. Tampilan skenario jaringan metro ethernet kondisi normal Kota Surabaya tahun 2028.

Jaringan metro ethernet yang disimulasikan menggunakan 4 topologi ring jaringan yang saling terhubung dan seluruhnya terdiri dari 16 grup node dengan 2 tipe node yang berbeda fungsi. Pada dasarnya, fungsi dari perangkat metro ethernet adalah sebagai switching disertai fungsi tambahan routing untuk meneruskan dan mentransmisikan paket data yang telah dibangkitkan. Node Huawei Quidway CX600-16 berfungsi sebagai perangkat metro ethernet (router switch) dan node ethernet_server adalah sebagai perangkat untuk mengasumsikan pembangkitan trafik jaringan. Sementara untuk media transmisi sebagai penghubung antar node, menggunakan empat jenis media transmisi yaitu 1Gbps ethernet, 10Gbps ethernet, 40Gbps ethernet dan 100Gbps ethernet. 
Tabel 3. Konfigurasi umum perangkat router switch dan server.

\begin{tabular}{lcc}
\hline \multicolumn{1}{c}{ Atribut } & router switch & server \\
\hline Interface & (Adjustable) & IF08 \\
MTU & Ethernet & Ethernet \\
Processing Scheme & Central Processing & CentralProcessing \\
Datagram Switching Rate & $500.000 \mathrm{pps})$ & $500.000 \mathrm{pps}$ \\
Forwarding Rate Units & packets/sec & packets/sec \\
Memory Size & $512 \mathrm{MB}$ & $256 \mathrm{MB}$ \\
Qos Scheme & FIF0 & FIF0 \\
Buffer Size & $2 \mathrm{Mbytes}$ & 2 Mbytes \\
Interface Speed & $10 \mathrm{Mbps}$ & \\
\hline
\end{tabular}

Tabel 4. Konfigurasi umum perangkat router switch dan server.

\begin{tabular}{|c|c|}
\hline Atribut & Settingan \\
\hline Model & $\begin{array}{l}\text { 1Gbps_Ethernet (Blue \#004080) } \\
\text { 10Gbps_Ethernet (Yellow) } \\
\text { 40Gbps_Ethernet (Green \#008000) } \\
\text { 100Gbps_Ethernet (Red \#850000) }\end{array}$ \\
\hline Propagation Speed & Speed of Light (in glass) \\
\hline BER & 1.00E-09 \\
\hline Condition & Enabled \\
\hline Data rate & $1 \mathrm{Gbps}, 10 \mathrm{Gbps}, 40 \mathrm{Gbps}, 100 \mathrm{Gbps}$ \\
\hline Delay (Propagation) & Distance Based \\
\hline
\end{tabular}

Simulasi jaringan metro ethernet ini dijalankan selama 1 jam dengan nilai per statistik yang digunakan adalah 100.

\subsection{Pengukuran QoS}

Pada pengukuran QoS untuk performansi link, langkahlangkah yang dilakukan adalah dengan memilih statistic pada scenario jaringan kondisi normal yang berkaitan dengan parameter yang akan diukur yaitu, round trip delay, jitter dan packet loss. Setelah itu, simulasi akan dijalankan hingga selesai untuk memperoleh hasil pengukuran. Standarisasi dari ketiga parameter berdasarkan ITU-T[x] ditampilkan pada Tabel 5.

Tabel 5. Standarisasi pengukuran QoS.

\begin{tabular}{ll}
\hline Parameter & Standar ITU-T \\
\hline Round trip delay (RTD) & $<5 \mathrm{msec}$ \\
Jitter & $<1 \mathrm{msec}$ \\
Packet loss & $<0,001 \%$ \\
\hline
\end{tabular}

\subsubsection{Round trip delay (RTD)}

Delay (end-to-end delay) adalah waktu tunda suatu paket yang diakibatkan oleh proses transmisi dari satu titik ke titik lain tujuannya. Delay dalam suatu jaringan juga merupakan parameter yang dapat dijadikan acuan dalam menilai kualitas dan kehandalan link. Sementara round trip delay (RTD), merupakan penjumlahan dari dua nilai delay. Pada penelitian ini, RTD adalah penjumlahan dari delay paket data dan delay ACK dimana ACK diasumsikan memiliki ukuran paket sebesar 40 bytes[7]. Perlu diketahui, analisis untuk delay antrian dalam node yang terukur dalam delay proses dari delay total menggunakan model antrian tunggal (single quеие). Pengukuran antrian tunggal dilakukan berdasarkan antrian point-to-point antar node dan bukan antrian keseluruhan jaringan (quеueing network). Untuk mencari RTD, dapat dihitung dengan persamaan (1).

$$
\mathrm{T}=(\tau \mathrm{T}+\tau \text { Prop }+\tau \text { Proc })+(\text { ack }+\tau \text { Prop }+\tau \text { Proc })
$$

keterangan:

$$
\begin{aligned}
& \mathrm{T}=\text { delay total }(\mathrm{s} \text { atau } \mathrm{ms}) \\
& \tau \mathrm{T}=\text { delay transmisi }(\mathrm{s} \text { atau } \mathrm{ms}) \\
& \tau \text { Prop }=\text { delay propagasi }(\mathrm{s} \text { atau } \mathrm{ms}) \\
& \tau \text { Proc }=\text { delay proses }(\mathrm{s} \text { atau } \mathrm{ms}) \\
& \tau \mathrm{ack}=\text { delay transmisi ACK }(\mathrm{s} \text { atau } \mathrm{ms})
\end{aligned}
$$

\subsubsection{Jitter}

Jitter dapat didefinisikan sebagai total variasi delay antara blok-blok informasi yang berurutan. Besarnya nilai jitter akan sangat dipengaruhi oleh variasi beban trafik yang ada dalam jaringan hingga berpeluang menimbulkan tumbukan antar paket (collision). Besarnya nilai jitter menandakan performansi link pada jaringan tersebut buruk sehingga nilai jitter harus dijaga seminimal mungkin. Perbedaan delay dengan jitter terletak pada waktu keterlambatannya. Delay memiliki keterlambatan yang konstan pada tiap waktunya, sedangkan perbedaan waktu keterlambatan pada jitter cenderung tidak menentu. Dalam OPNET, jitter disebut juga total variasi end-to-end delay dan untuk mengukurnya menggunakan persamaan (2).

$$
\operatorname{Jitter}(s)=\sqrt{(\text { delay yang terjadi }- \text { rerata delay })}^{2}
$$

\subsubsection{Packet Loss}

Packet loss didefinisikan sebagai kegagalan transmisi paket data untuk mencapai tujuannya. Dalam jaringan IP, nilai packet loss ini diharapkan mempunyai nilai yang sekecil mungkin. Kegagalan paket data dalam mencapai tujuan dapat disebabkan oleh beberapa kemungkinkan, diantaranya adalah terjadinya error transmisi, TTL (Time To Live) paket data tidak tercapai, terjadinya kemacetan (congestion) dan luapan trafik (overflow), hingga kerusakan perangkat media fisik. Untuk pengukuran packet loss, dapat menggunakan persamaan (3).

Packet Loss $=\frac{\text { Packet sent }- \text { Packet received }}{\text { Packet Sent }} \times 100 \%$

\section{Hasil dan Analisis \\ 3.1. Analisis Kinerja Routing Protocol}

Analisis evaluasi kinerja routing protocol dilakukan dengan membandingkan hasil dari dua metode scenario yang digunakan yaitu one link flapping dan two links flapping dari setiap protocol routing. Parameter yang akan 
dianalisis adalah waktu konvergensi (convergence time), packet drop dan HTTP respon time.

Pada skenario pertama akan dilakukan one link flapping dimana pada detik yang telah ditentukan link antara node ME-MNR dan ME-DMO dikonfigurasikan failure dan recovery. Sedangkan pada skenario kedua akan dilakukan konfigurasi two link flapping dimana pada konfigurasi failure dan recovery ditambahkan satu link tambahan yaitu diantara node router ME-KBL dan ME-MNR.

Tabel 6. Statistik one link flapping.

\begin{tabular}{ccc}
\hline Parameter & \multicolumn{2}{c}{ Routing protocol } \\
& OSPF & RIP \\
\hline Waktu Konvergensi (sec) & 4.295539841 & 61.81336348 \\
Packet drop (packets/sec) & 0 & 0.086036295 \\
HTTP page respon time $(\mathrm{sec})$ & 0.496113715 & 0.470119665 \\
\hline
\end{tabular}

Tabel 7. Statistik two links flapping.

\begin{tabular}{ccc}
\hline Parameter & \multicolumn{2}{c}{ Routing protocol } \\
& OSPF & RIP \\
\hline Waktu Konvergensi (sec) & 8.521460184 & 67.18429398 \\
Packet drop (packets/sec) & 0 & 0.20820222 \\
HTTP page respon time (sec) & 0.364938125 & 0.382622499 \\
\hline
\end{tabular}

Dalam penelitian ini telah diamati waktu konvergensi jaringan, packet drop dan HTTP page respon time untuk routing protocol OSPF dan RIP. Dari hasil simulasi dapat kita simpulkan bahwa ketika terdapat ketidakstabilan pada satu link, waktu konvergensi routing protocol OSPF lebih baik daripada routing protocol RIP dengan selisih nilai 57.51782364 detik. Waktu konvergensi routing protocol OSPF ketika terdapat ketidakstabilan pada dua link juga lebih baik dibandingkan waktu konvergensi routing protocol RIP dengan selisih nilai 58.6628338 detik. Untuk nilai packet drop, routing protocol OSPF memiliki nilai 0 pada kedua pengujian baik pada one link flapping maupun two links flapping, hal ini menunjukkan bahwa routing protocol OSPF tidak mengalami packet drop pada jaringannya.

Untuk parameter HTTP page respon time antara routing protocol OSPF dan RIP, keduanya memiliki rata-rata waktu respon yang hampir sama saat kedaan tidak stabil pada satu dan dua link. Pada keadaan one link flapping, waktu respon HTTP routing protocol RIP lebih cepat dibandingkan dengan OSPF dengan nilai selisih 0.025994049 detik. Namun pada keadaan two links flapping, routing protocol OSPF memiliki waktu respon HTTP yang lebih cepat dibandingkan dengan RIP dengan nilai selisih 0.017684374 detik.

Kesimpulan dalam pengujian ini adalah bahwa ketika terdapat ketidakstabilan pada satu dan dua link berdasarkan parameter waktu konvergensi, packet drop dan HTTP page respon time, kinerja routing protocol OSPF lebih baik dibandingkan dengan kinerja routing protocol RIP. Oleh karena itu, untuk jaringan pada kondisi normal dalam simulasi penelitian ini akan menggunakan OSPF sebagai routing protocol-nya.

\subsection{Analisis Jaringan Kondisi Normal}

Pada bagian ini akan dilakukan analisis jaringan dalam kondisi normal untuk performansi link berdasarkan parameter round trip delay, jitter dan packet loss. Analisis performansi link untuk tiap parameter dilakukan berdasarkan standarisasi dari ITU-T.

\subsubsection{DES Log Viewer}

Simulasi yang dimodelkan pada seluruh skenario telah berjalan sesuai harapan. Hal tersebut terlihat pada jendela DES Log Viewer dimana hanya terdapat keterangan dengan kategori sebatas pemberitahuan (kondisi normal/warna hijau) dan bukan merupakan peringatan ataupun error (kondisi kritis/warna merah). Skenario dilakukan selama 1 jam dan untuk tampilan menu DES Log Viewer ditunjukkan pada Gambar 5.

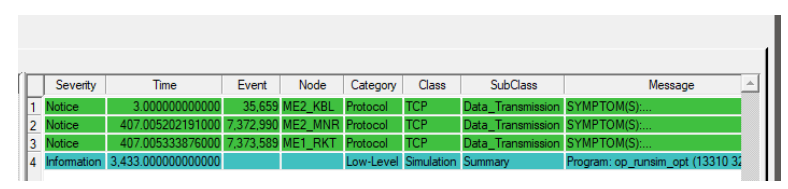

Gambar 5. DES Log Viewer simulasi dengan terdapat 4 log.

\subsubsection{Pengukuran parameter QoS}

Tabel 8. Pengukuran parameter QoS untuk performansi link.

\begin{tabular}{cllccccc}
\hline \multirow{2}{*}{ No. } & \multicolumn{2}{c}{ NODE } & \multicolumn{2}{c}{ RTD (ms) } & \multicolumn{2}{c}{ Jitter rata-rata (ms) } & \multicolumn{2}{c}{ Packet loss } \\
& Asal & Tujuan & IN & OUT & IN & OUT & rata-rata (\%) \\
\hline 1 & MNR & DMO & 0.107 & 0.128 & 0.001 & 0.008 & 0.0004 \\
2 & JGR & GUB & 0.326 & 0.319 & 0.015 & 0.008 & 0.0000 \\
3 & LKS & GUB & 0.166 & 0.175 & 0.009 & 0.014 & 0.0001 \\
4 & LKS & IJK & 0.139 & 0.134 & 0.014 & 0.011 & 0.0003 \\
5 & KLA & KBL & 0.133 & 0.131 & 0.014 & 0.012 & 0.0005 \\
6 & KPS & KJR & 0.129 & 0.128 & 0.015 & 0.015 & 0.0002 \\
7 & TDS & KLA & 0.106 & 0.109 & 0.008 & 0.011 & 0.0002 \\
8 & KBL & KNN & 0.162 & 0.161 & 0.009 & 0.008 & 0.0001 \\
9 & MGO & KPS & 0.4 & 0.395 & 0.011 & 0.006 & 0.0000 \\
10 & LKS & KRP & 0.116 & 0.118 & 0.011 & 0.012 & 0.0002 \\
11 & KJR & KTT & 0.177 & 0.178 & 0.010 & 0.012 & 0.0001 \\
12 & DMO & MGO & 0.097 & 0.086 & 0.015 & 0.008 & 0.0003 \\
13 & KBL & MNR & 0.154 & 0.151 & 0.012 & 0.011 & 0.0004 \\
14 & MNR & RKT & 0.297 & 0.332 & 0.041 & 0.077 & 0.0000 \\
15 & KRP & TDS & 0.337 & 0.335 & 0.010 & 0.008 & 0.0000 \\
16 & JGR & IJK & 0.116 & 0.129 & 0.007 & 0.014 & 0.0004 \\
17 & LKS & KNN & 0.13 & 0.129 & 0.009 & 0.008 & 0.0001 \\
18 & MNR & KTT & 0.138 & 0.14 & 0.008 & 0.008 & 0.0001 \\
19 & KBL & RKT & 0.172 & 0.167 & 0.008 & 0.0031 & 0.0004 \\
\hline
\end{tabular}

Menurut grafik Gambar 6, 7 dan 8 dapat diketahui bahwa nilai round trip delay, jitter dan packet loss pada keseluruhan link jaringan berada di bawah batas standarisasi ITU-T dengan nilai kurang dari $5 \mathrm{~ms}$, $1 \mathrm{~ms}$ dan $0.001 \%$. Hal ini menunjukkan bahwa link yang bekerja pada jaringan memiliki performansi yang baik. 


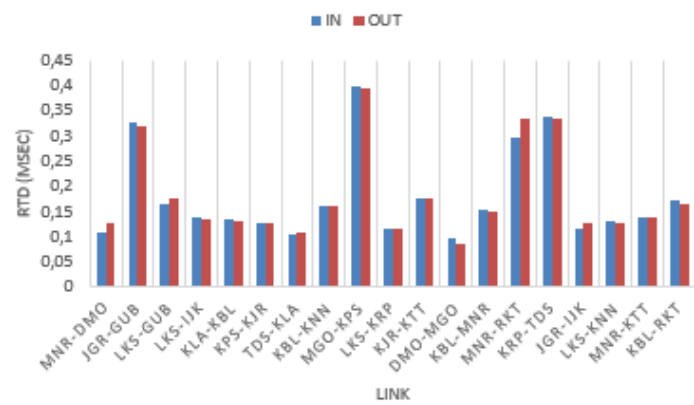

Gambar 6. Grafik round trip delay per link.

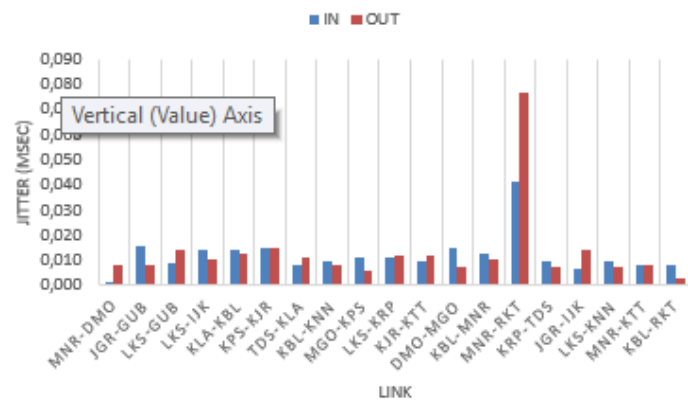

Gambar 7. Grafik jitter per link.

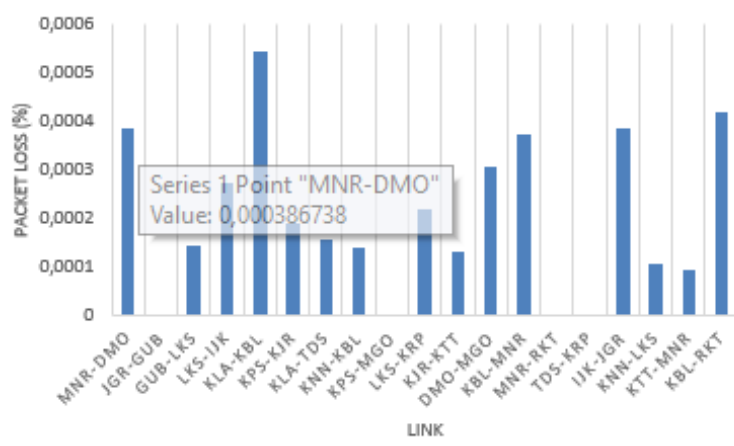

Gambar 8. Grafik packet loss per link.

Nilai RTD yang paling baik, terdapat pada link DMOMGO dan arah sebaliknya. Kedua link tersebut memiliki nilai RTD berturut-turut $0.09658 \mathrm{~ms}$ dan $0.08563 \mathrm{~ms}$. Link dengan nilai RTD tertinggi adalah pada link MGO-KPS dan arah sebaliknya yaitu berturut-turut $0.39971 \mathrm{~ms}$ dan 0.39473 ms. Nilai jitter yang paling baik, untuk link inbound terdapat pada link MNR-DMOdengan nilai sebesar $0.0012 \mathrm{~ms}$, sedangkan untuk link outbound terdapat pada link KBL-RKT dengan nilai 0.0031. Link dengan nilai jitter paling tinggi adalah pada link MNRRKT dan sebaliknya dengan nilai rata-rata jitter berturutturut sebesar $0.0413 \mathrm{~ms}$ dan $0.0765 \mathrm{~ms}$. Nilai packet loss tertinggi dibandingkan dengan link-link lainnya terdapat pada link KLA-KBL dengan nilai $0.00054 \%$.

\subsection{Analisis Perbandingan Hasil Perhitungan dan Simulasi Pada Jaringan}

Analisis perbandingan hasil perhitungan dan simulasi pada jaringan metro ethernet ini menggunakan parameter utilisasi dan volume trafik. Hasil perhitungan kedua parameter menggunakan data dari penelitian yang telah dilakukan sebelumnya. Analisis perbandingan dilakukan dengan menyajikan tabel dan grafik untuk tiap parameter.

Tabel 9. Perbandingan selisih hasil perhitungan dan simulasi pada jaringan.

\begin{tabular}{|c|c|c|c|c|c|c|}
\hline \multirow{2}{*}{ No. } & \multicolumn{2}{|c|}{ Node } & \multicolumn{2}{|c|}{$\begin{array}{c}\text { Selisih } \\
\text { Utilisasi }\end{array}$} & \multicolumn{2}{|c|}{ Selisih Volume Trafik } \\
\hline & Asal & Tujuan & IN & OUT & IN & OUT \\
\hline 1 & MNR & DMO & $0.01 \%$ & $0.32 \%$ & $0.03 \%$ & $0.76 \%$ \\
\hline 2 & JGR & GUB & $0.15 \%$ & $0.44 \%$ & $0.34 \%$ & $1.06 \%$ \\
\hline 3 & GUB & LKS & $0.10 \%$ & $0.19 \%$ & $0.17 \%$ & $0.34 \%$ \\
\hline 4 & LKS & IJK & $0.24 \%$ & $0.29 \%$ & $0.50 \%$ & $1.00 \%$ \\
\hline 5 & $\mathrm{KLA}$ & KBL & $0.13 \%$ & $0.16 \%$ & $0.28 \%$ & $0.33 \%$ \\
\hline 6 & KPS & KJR & $0.06 \%$ & $0.01 \%$ & $0.11 \%$ & $0.02 \%$ \\
\hline 7 & TDS & $\mathrm{KLA}$ & $0.24 \%$ & $0.05 \%$ & $0.95 \%$ & $0.44 \%$ \\
\hline 8 & KBL & KNN & $0.06 \%$ & $0.14 \%$ & $0.16 \%$ & $0.38 \%$ \\
\hline 9 & MGO & KPS & $0.02 \%$ & $0.14 \%$ & $0.04 \%$ & $0.26 \%$ \\
\hline 10 & LKS & KRP & $0.00 \%$ & $0.29 \%$ & $0.09 \%$ & $0.56 \%$ \\
\hline 11 & KJR & KTT & $0.03 \%$ & $0.16 \%$ & $0.08 \%$ & $0.52 \%$ \\
\hline 12 & DMO & MGO & $0.04 \%$ & $0.20 \%$ & $0.10 \%$ & $0.43 \%$ \\
\hline 13 & KBL & MNR & $0.13 \%$ & $0.13 \%$ & $0.36 \%$ & $0.33 \%$ \\
\hline 14 & MNR & RKT & $0.04 \%$ & $0.16 \%$ & $0.10 \%$ & $0.35 \%$ \\
\hline 15 & KRP & TDS & $0.09 \%$ & $0.25 \%$ & $0.19 \%$ & $0.47 \%$ \\
\hline 16 & IJK & JGR & $0.07 \%$ & $0.27 \%$ & $0.15 \%$ & $0.60 \%$ \\
\hline 17 & KNN & LKS & $0.18 \%$ & $0.02 \%$ & $0.70 \%$ & $0.43 \%$ \\
\hline 18 & KTT & MNR & $0.13 \%$ & $0.02 \%$ & $0.41 \%$ & $0.06 \%$ \\
\hline 19 & RKT & KBL & $0.22 \%$ & $0.53 \%$ & $0.27 \%$ & $0.44 \%$ \\
\hline
\end{tabular}

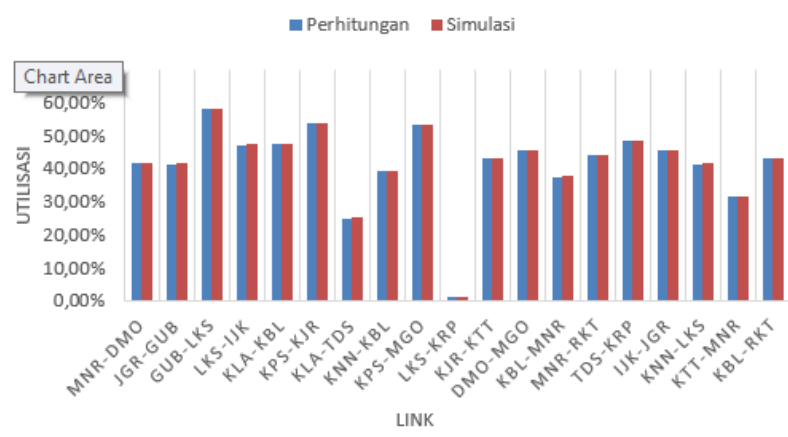

Gambar 9. Perbandingan parameter utilisasi hasil perhitungan dan simulasi pada link inbound 


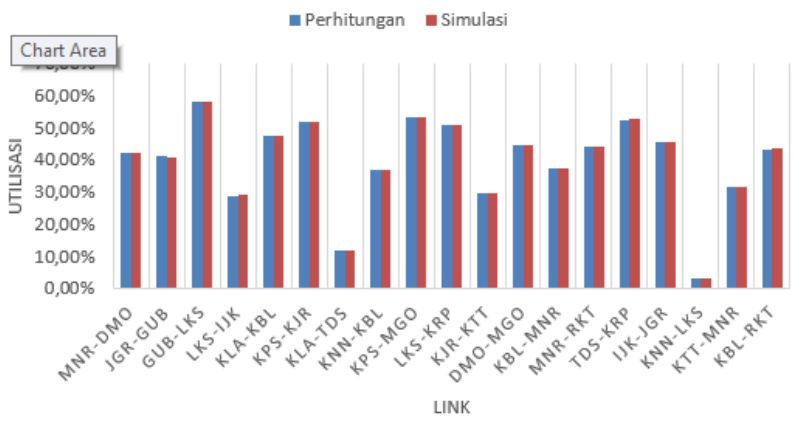

Gambar 10. Perbandingan parameter utilisasi hasil perhitungan dan simulasi pada link outbound

Berdasarkan Gambar 9 dan 10 dapat diketahui bahwa perbandingan hasil perhitungan dan simulasi pada parameter utilisasi menunjukkan bahwa keduanya memiliki nilai yang hampir sama dengan nilai selisih pada rentang 0\% sampai $0.53 \%$. Selisih nilai utilisasi terbesar link inbound terdapat pada link LKS-IJK sedangkan link outbound pada link RKT-KBL dengan selisih nilai berturut-turut sebesar $0.24 \%$ dan $0.53 \%$. Untuk selisih nilai hasil perhitungan dan hasil simulasi terkecil pada link inbound pada link LKS-KRP sedangkan pada link outbound pada link KPS-KJR dengan selisih nilai berturutturut sebesar $0 \%$ dan $0.01 \%$.

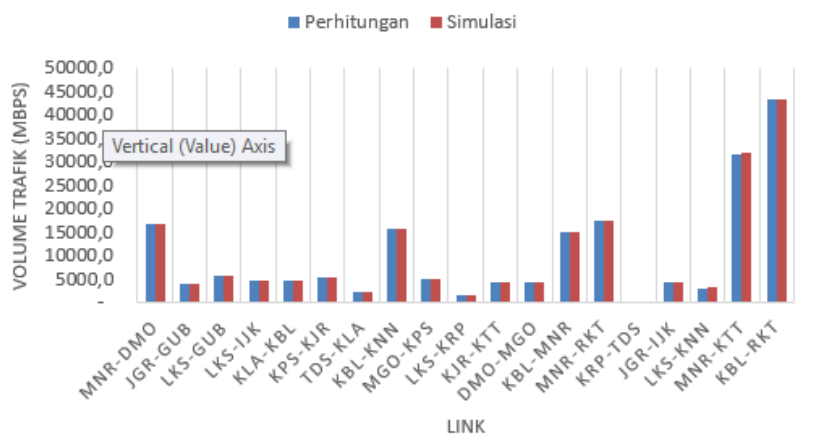

Gambar 11. Perbandingan parameter volume trafik hasil perhitungan dan simulasi pada link inbound.

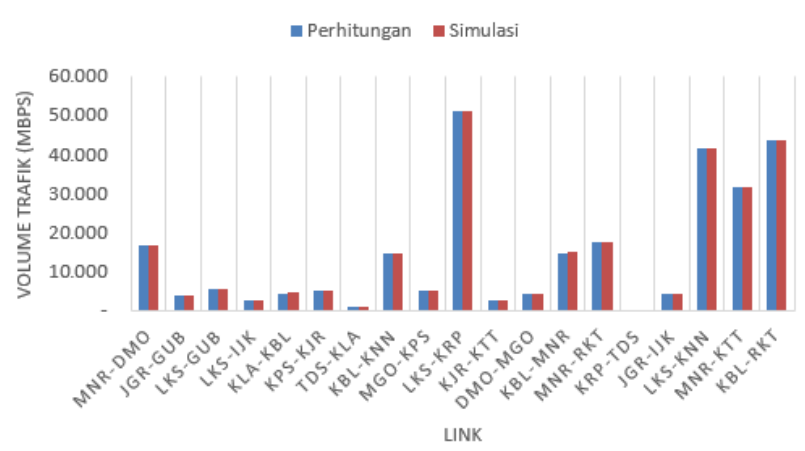

Gambar 12. Perbandingan parameter volume trafik hasil perhitungan dan simulasi pada link outbound
Berdasarkan Gambar 11 dan 12 dapat diketahui bahwa perbandingan hasil perhitungan dan simulasi pada parameter volume trafik menunjukkan bahwa keduanya memiliki nilai yang hampir sama dengan nilai selisih pada rentang $0.017 \%$ sampai $1.064 \%$. Selisih nilai terkecil link inbound terdapat pada link MNR-DMO sedangkan link outbound pada link KPS-KJR dengan nilai berturut-turut $0.031 \%$ dan $0.017 \%$. Selisih nilai terbesar pada link inbound terdapat pada link TDS-KLA dan link outbound pada link JGR-GUB dengan nilai berturut-turut sebesar $0.953 \%$ dan $1.064 \%$.

\section{Kesimpulan}

Berdasarkan hasil penelitian ini, ketika terdapat ketidakstabilan pada satu dan dua link berdasarkan parameter waktu konvergensi, packet drop dan HTTP page respon time, kinerja routing protocol OSPF lebih baik dibandingkan dengan kinerja routing protocol RIP. Oleh karena itu, untuk jaringan pada kondisi normal dalam simulasi penelitian ini akan menggunakan OSPF sebagai routing protocol-nya. Nilai round trip delay, jitter dan packet loss pada keseluruhan link jaringan berada di bawah batas standarisasi ITU-T dengan nilai kurang dari 5ms, $1 \mathrm{~ms}$ dan $0.001 \%$. Hal ini menunjukkan bahwa link yang bekerja pada jaringan memiliki performansi yang baik.. Link dengan nilai RTD paling tinggi adalah pada link MGO-KPS dan arah sebaliknya yaitu berturut-turut $0.39971 \mathrm{~ms}$ dan $0.39473 \mathrm{~ms}$. Link dengan nilai jitter paling tinggi adalah pada link MNR-RKT dan sebaliknya dengan nilai rata-rata jitter berturut-turut sebesar $0.0413 \mathrm{~ms}$ dan $0.0765 \mathrm{~ms}$. Nilai packet loss tertinggi dibandingkan dengan link-link lainnya terdapat pada link KLA-KBL dengan nilai $0.00054 \%$. Perbandingan hasil perhitungan dan simulasi pada parameter utilisasi menunjukkan bahwa keduanya memiliki nilai yang hampir sama dengan nilai selisih pada rentang $0 \%$ sampai $0.53 \%$. Perbandingan hasil perhitungan dan simulasi pada parameter volume trafik menunjukkan bahwa keduanya memiliki nilai yang hampir sama dengan nilai selisih pada rentang $0.017 \%$ sampai $1.064 \%$.

\section{Referensi}

[1]. Sekarwangi, A. P. (2018). Perancangan Jaringan Metro Ethernet Kota Surabaya Tahun 2028 Dengan Metode Peramalan Trafik Rapp's Formula Dan Pengelompokan Trafik Dengan Metode Traffic Grooming. Penelitian Penelitian Departemen Teknik Elektro Fakultas Teknik Universitas Diponegoro.

[2]. Sitompul, K. R. (2009). Analisis Kinerja Jaringan Metropolitan Area Network Dengan Teknologi Metro Ethernet (Studi Kasus PT Telkom Medan). Penelitian Departemen Teknik Elektro Fakultas Teknik Universitas Sumatera Utara Medan.

[3]. Pratama, S. Y., Sukiswo, \& Zahra, A. A. (2017). Analisis Performansi Link Pada Jaringan Metro Ethernet Regional Jawa Tengah Menggunakan Simulator Opnet 14 . 5. Penelitian Departemen Teknik Elektro Fakultas Teknik Universitas Diponegoro, 6(1), 117. 
[4]. Nurhayati, A., Posma, R., \& Maulana, K. N. (n.d.). Analisis Routing Pada Ospf Metro Ethernet Pt. Telekomunikasi Indonesia. Ict Penelitian Dan Penerapan Teknologi, 4(6), 7-14.

[5]. Iqbal, A., \& Khan, S. L. A. (2015). Performance Evaluation of Real Time Applications for RIP, OSPF and EIGRP for flapping links using OPNET Modeler. International Journal of Computer Networks and Communications Security, 3(1), 16-26.
[6]. M. Sarosa dan S. Anggoro. Data Link, Network \& Issue Jaringan Komputer. Elektroteknik Teknik Sistem Komputer Institut Teknologi Bandung, 2000.

[7]. B. Chen, I. Marsic, H.-R. Shao, and R. Miller (2009), "Improved Delayed ACK for TCP over Multi-Hop Wireless Networks," IEEE Commun. Soc., no. January 2015, pp. 1-6. 